Original Article

\title{
Prevalence of Substance Abuse and Related Factors in Type 2 Diabetic Patients Living in a Rural Area in Northern Iran
}

\author{
Mohammad Shokrzadeh ${ }^{1}$, Ali Savarolia ${ }^{2}$, Danial Jafari², Reza Hoseinpoor ${ }^{2}$, Hajar Serayeloo ${ }^{2}$, \\ Elham Masodi ${ }^{2}$, Mehrnoosh Deylami ${ }^{2}$, Maryam Tajari ${ }^{2}$, Yaghoub Shayeste ${ }^{*^{2}}$ \\ 1. Pharmaceutical Sciences Research Center, Department of Pharmacology and Toxicology, Faculty of \\ Pharmacy, Mazandaran University of Medical Sciences, Sari, Iran \\ 2.Health Management and Social Development Research Center, Golestan University of Medical \\ Sciences, Gorgan, Iran \\ *Correspondence: Yaghoub Shayeste, Health Management and Social Development Research Center, \\ Golestan University of Medical Sciences, Gorgan, Iran \\ Tel: +989113738979 \\ Email: shayeste.yaghoub@gmail.com
}

Received December 10, 2020

Accepted December 30, 2020

\begin{abstract}
Background and objectives: Diabetes is one of the most important diseases in the world. Substance abuse is one of the most important social problems in Iran. The aim of this study was to determine the prevalence of substance abuse and related factors in type 2 diabetic patients living in a rural area in northeastern Iran.

Methods: This was a cross-sectional study that was performed in 2018 on all diabetic patients $(\mathrm{n}=757)$ living in rural areas of Bandar-e-Gaz, northeastern Iran. Data were collected from patients' records and using a checklist comprising of 20 questions on demographic characteristics, history of type 2 diabetes and history of substance/drug abuse. Data analysis was performed with SPSS software using Pearson's correlation coefficient and the chi-square test.

Results: The mean age of diabetic patients was $59.9 \pm 8.14$ years (range: $12-92$ years). The frequency of smoking was $6.7 \%$ among the patients. The frequency of substance abuse in diabetic patients was $9.3 \%$ $(n=70)$. Among the substance abusers, $76.3 \%$ were male and $42.5 \%$ were aged $50-59$ years. Opium was the most commonly abused substance among diabetics (90\%). According to the subjects, diabetes and its complications were the most important reason for substance abuse $(74.3 \%)$. There was a statistically significant relationship between substance abuse in diabetic patients and some factors including gender, age, marital status, income level, treatment method and presence of diabetic complications $(\mathrm{P}<0.001)$.

Conclusion: Opium is the most commonly abused substance abuse among type 2 diabetic patients living in rural areas of Bandar-e-Gaz. In addition, substance abuse is more common among middle-aged men, farmers, married individuals as well as those with primary education and diabetes for 2-5 years.

Keywords: Type 2 diabetes mellitus; Substance abuse; Prevalence
\end{abstract}

DOI: $10.29252 / J c b r .4 .4 .41$ 


\section{INTRODUCTION}

Diabetes is an important metabolic disorder characterized by hyperglycemia caused by impaired insulin secretion, insulin dysfunction or both (1). Type 2 diabetes mellitus, also known as non-insulin dependent diabetes, accounts for more than $90 \%$ of all cases of diabetes and is associated with insulin resistance, which can lead to beta cell dysfunction and impaired insulin production $(1,2)$. Age of more than 40 years, overweight, obesity and a positive family history of diabetes are the most important risk factors of type 2 diabetes (2). Due to various life-threatening complications, diabetes is a global health concern (3). According to the World Health Organization (WHO), the number of people with diabetes will exceed half a billion people by 2030 (4). Diabetes is a leading cause of morbidity and mortality worldwide. It is estimated that diabetes alone is responsible for four million deaths annually $(5,6)$.

In general, substance abuse is a term defined as the use of illegal drugs or chemicals or the misuse of permitted drugs and chemicals for non-therapeutic purposes. According to the WHO, substance abuse is a global health problem. Opioids, stimulants, alcohol, some drugs, crack, methamphetamine, etc. are the most important addictive substances that are abused in most countries (7). According to reports, Iran ranks second in the world in terms of substance abuse (8).

Studies show that substance abuse is common among diabetic patients (5). For instance, in Iran, the rate of substance abuse in diabetic patients is higher than in the general population (11.2\% vs. $8.2 \%$ ) (9). In addition, due to misconceptions, substance abuse is common among diabetics with the motive of lowering blood sugar and relieving diabetes complications (10). According to some studies, substance abuse can worsen hyperglycemia and increase the risk of impaired lipid metabolism as well as diabetic complications such as neuropathy and retinopathy $(5,11,12)$. These substances can also cause poor glycemic control in diabetics by reducing the absorption and function of insulin. In addition, substance abuse imposes a significant economic burden on the patients and the whole society (13-17). Therefore, due to the increasing prevalence of diabetes, especially type 2 diabetes, and the health significance of its complications, it is essential to determine the prevalence of substance abuse among diabetic patients in order to establish necessary plans to control and prevent this problem to reduce the risk of poor glycemic control and development of diabetic complications among this group of people. Therefore, this study was performed to determine the prevalence of substance abuse and related factors in type 2 diabetic patients living in rural areas of Bandar-e-Gaz in Golestan Province, northeastern Iran.

\section{MATERIALS AND METHODS}

This was a descriptive cross-sectional study that was performed in 2018 , on all adult type 2 diabetic patients (aged 12 years and older) who were living in rural areas of Bandar-e-Gaz, northeastern Iran. Inclusion criteria were having type 2 diabetes for at least six months, living in one of the villages of Bandar-e-Gaz in the last six months, having Iranian nationality, age of 12 years and over and having a valid record in the health centers. Subjects were enrolled via census and written consent was obtained from all eligible individuals prior to participation in the study. The reason for choosing a time interval of six months was to minimize bias and to consider the minimum duration required for substance abuse to influence diabetes or its complications.

According to the latest census data, the total number of residents in rural areas of Bandar-e-Gaz was 19486, of which 757 had type 2 diabetes. Data related to these individuals were extracted from 18 health 
centers in the study area. Data were collected using a checklist comprising of 20 questions under three categories of demographic characteristics $(n=6)$, history of type 2 diabetes $(n=4)$ and history of substance/drug abuse $(n=10)$. Subjects who did not fully answer the checklist questions were excluded from the study. In this checklist, the term substance abuse included the use of one or more of the followings: cocaine, tramadol, codeine, lysergic acid diethylamide (LSD), opium, poppy juice, tobacco, naswar, heroin, crack and methamphetamines, crystal, cannabis, ecstasy, buprenorphine, over-the-counter sedatives or hypnotics, alcohol and other drugs or medications. The checklist was designed based on the variables studied in previous investigations and the opinion of three experts in the field of addiction and toxicology. The design and validity of the questionnaire were confirmed.

All subjects were invited via the routine follow-up program of the health centers and within four months. The checklist was completed in 20 minutes, by a clinical psychologist who was familiar with the study objectives and details. Answers were reported as mean frequency and percentage. The collected data were analyzed in SPSS 16 using the chi-square test. All analyses were performed at significance of 0.05 .

The study received approval from the ethics committee of the Golestan University of Medical Sciences, Iran (ethics code: IR.GOUMS.REC. 1397.113).

\section{RESULTS}

The demographic characteristics of the subjects are presented in table 1 . 
Table 1. Demographic characteristics of diabetic patients in rural areas of Bandar-e-Gaz, Iran

\begin{tabular}{|c|c|c|c|}
\hline Variable & Classification & Frequency & Percent \\
\hline \multirow{3}{*}{ Gender } & Male & 220 & 29.1 \\
\hline & Female & 537 & 70.9 \\
\hline & Total & 757 & 100 \\
\hline \multirow{5}{*}{$\begin{array}{l}\text { Age group } \\
\text { (years) }\end{array}$} & $<30$ & 2 & 0.3 \\
\hline & $30-39$ & 27 & 3.6 \\
\hline & $40-49$ & 112 & 14.8 \\
\hline & $50-59$ & 236 & 31.2 \\
\hline & $>60$ & 380 & 50.2 \\
\hline \multirow{8}{*}{ Occupation } & Unemployed & 20 & 2.6 \\
\hline & Homemaker & 509 & 67.2 \\
\hline & Employee & 16 & 2.1 \\
\hline & Farmer & 87 & 11.5 \\
\hline & Retired & 50 & 6.6 \\
\hline & Freelance & 59 & 7.8 \\
\hline & Other & 16 & 2.1 \\
\hline & Total & 757 & 100 \\
\hline \multirow{5}{*}{ Marital status } & Single & 19 & 2.5 \\
\hline & Married & 602 & 79.5 \\
\hline & Widowed & 123 & 16.3 \\
\hline & Divorced & 13 & 1.7 \\
\hline & Total & 757 & 100 \\
\hline \multirow{6}{*}{ Education level } & Illiterate & 342 & 45.2 \\
\hline & Primary & 182 & 24 \\
\hline & Secondary & 156 & 20.6 \\
\hline & High school & 75 & 9.9 \\
\hline & University degree & 2 & 0.3 \\
\hline & Total & 757 & 100 \\
\hline \multirow{4}{*}{$\begin{array}{l}\text { Income } \\
\text { (Tomans) }\end{array}$} & Less than 4 million & 430 & 56.8 \\
\hline & 1-3 million & 312 & 41.2 \\
\hline & $\begin{array}{l}\text { More than } 3 \\
\text { million }\end{array}$ & 15 & 2 \\
\hline & Total & 757 & 100 \\
\hline \multirow{4}{*}{$\begin{array}{l}\text { Treatment } \\
\text { method }\end{array}$} & Medication & 641 & 84.7 \\
\hline & Insulin & 52 & 6.9 \\
\hline & $\begin{array}{l}\text { Medication and } \\
\text { insulin }\end{array}$ & 64 & 8.5 \\
\hline & Total & 757 & 100 \\
\hline \multirow{7}{*}{$\begin{array}{l}\text { Age at time of } \\
\text { onset (years) }\end{array}$} & $12-19$ & 5 & 0.7 \\
\hline & $20-29$ & 10 & 1.3 \\
\hline & $30-39$ & 80 & 10.6 \\
\hline & $40-49$ & 253 & 33.4 \\
\hline & $50-59$ & 250 & 33 \\
\hline & $>60$ & 159 & 21 \\
\hline & Total & 757 & 100 \\
\hline \multirow{8}{*}{$\begin{array}{c}\text { History of } \\
\text { diabetes (years) }\end{array}$} & Less than 2 & 127 & 16.8 \\
\hline & $2-5$ & 167 & 22.1 \\
\hline & $6-9$ & 167 & 22.1 \\
\hline & $10-14$ & 141 & 18.6 \\
\hline & $15-19$ & 83 & 11 \\
\hline & $20-24$ & 42 & 5.6 \\
\hline & $>25$ & 30 & 4 \\
\hline & Total & 757 & 100 \\
\hline
\end{tabular}


Overall, 80 subjects $(10.6 \%)$ had a positive history of substance abuse, of whom 70 $(9.3 \%)$ were still with the condition. Based on the results, $59(7.8 \%)$ subjects had a history of smoking, of whom $46(6.1 \%)$ were still smoking in the past 30 days $(\mathrm{P}=0.04)$. Previous history of substance abuse in the immediate family members was present in 85 patients $(11.2 \%)$.

We found that $23.6 \%$ of all diabetic men and $3.4 \%$ of all diabetic women were substance abusers (Table 2). The frequency of substance abuse was highest among diabetics aged $50-59$ years $(42.5 \%)$.

Opium was the most commonly abused substance (90\%), while it was used in combination with other drugs in seven cases $(9.7 \%)$.

Out of 70 diabetic patients who were uffering from substance abuse in the past 30 days, 61 cases $(87.1 \%)$ used opium, six cases $(8.6 \%)$ used poppy juice, one case $(1.4 \%)$ used codeine tablets, one case $(1.4 \%)$ was alcoholic and another case $(1.4 \%)$ used stimulants. Moreover, 65 cases (92.9\%) were using drugs every day.

The predominant methods of substance abuse were inhalation (52.5\%), oral consumption (37.5\%) and smoking (10\%). Starting substance abuse was more common at age of $45-49$ years $(25.7 \%)$, followed by age of 55 years and older (22.9\%) and 40-44 years $(21.4 \%)$.

Of 80 diabetics with history of substance abuse, $45(56.3 \%)$ started substance abuse after being diagnosed with diabetes. Among current substance abusers, 52 cases $(74.3 \%)$ reported diabetes and its complications as the reason for substance abuse (Table 2).

Table 2. The relationship between the frequency of substance abuse in diabetic patients and the variables under study

\begin{tabular}{|c|c|c|c|c|c|}
\hline \multicolumn{2}{|c|}{ Variable } & \multicolumn{3}{|c|}{ History of substance abuse } & P-value \\
\hline \multirow{3}{*}{ Gender } & Male & $\begin{array}{c}\begin{array}{c}\text { Positive } \\
\text { Number (\%) }\end{array} \\
61(76.3)\end{array}$ & $\begin{array}{c}\begin{array}{c}\text { Negative } \\
\text { Number }(\%)\end{array} \\
159(23.5)\end{array}$ & $\begin{array}{c}\begin{array}{c}\text { Total } \\
\text { Number }(\%)\end{array} \\
220(29.1)\end{array}$ & \multirow{3}{*}{0.001} \\
\hline & Female & 19(23.7) & $518(76.5)$ & $537(70.9)$ & \\
\hline & Total & $80(100)$ & $677(100)$ & $757(100)$ & \\
\hline \multirow{6}{*}{ Age (years) } & $<30$ & $0(0)$ & $(2(0.3)$ & $2(0.26)$ & \multirow{6}{*}{0.001} \\
\hline & $30-39$ & $2(2.5)$ & $25(3.7)$ & $27(3.6)$ & \\
\hline & $40-49$ & $13(16.3)$ & 99(14.6) & $112(14.8)$ & \\
\hline & $50-59$ & $34(42.5)$ & $202(29.8)$ & $236(31.2)$ & \\
\hline & $>60$ & $31(38.8)$ & $349(51.6)$ & $380(50.2)$ & \\
\hline & Total & $80(100)$ & $677(100)$ & $757(100)$ & \\
\hline \multirow{5}{*}{ Marital status } & Single & $8(10)$ & $11(1.6)$ & $19(2.5)$ & \multirow{5}{*}{0.001} \\
\hline & Married & $68(85)$ & 534(78.9) & $602(79.5)$ & \\
\hline & Widowed & $4(5)$ & $119(17.6)$ & $123(16.2)$ & \\
\hline & Divorced & $0(0)$ & $13(1.9)$ & $13(1.7)$ & \\
\hline & Total & $80(100)$ & $677(100)$ & $757(100)$ & \\
\hline \multirow{7}{*}{ Occupation } & Unemployed & $10(12.5)$ & $10(1.5)$ & $20(2.6)$ & \multirow{7}{*}{0.067} \\
\hline & Homemaker & $14(17.5)$ & $495(73.1)$ & $509(67.2)$ & \\
\hline & Employee & $2(2.5)$ & $(2.1)(14(2.1)$ & $16(2.1)$ & \\
\hline & Farmer & $26(32.5)$ & $61(9)$ & $87(11.5)$ & \\
\hline & Retired & $3(3.8)$ & $47(6.9)$ & $50(6.6)$ & \\
\hline & Freelance & $20(25)$ & $39(5.8)$ & 59(7.8) & \\
\hline & Other & $5(6.3)$ & 11(1.6) & $16(2.1)$ & \\
\hline
\end{tabular}




\begin{tabular}{|c|c|c|c|c|c|}
\hline & Total & $80(100)$ & $677(100)$ & $757(100)$ & \\
\hline \multirow{6}{*}{ Education level } & Illiterate & $19(23.8)$ & $323(47.7)$ & $342(45.2)$ & \multirow{6}{*}{0.07} \\
\hline & Primary & $30(37.5)$ & $152(22.5)$ & $182(24)$ & \\
\hline & Secondary & $25(31.3)$ & $131(17.3)$ & $156(20.6)$ & \\
\hline & High school & $6(7.5)$ & $69(10.2)$ & $75(9.9)$ & \\
\hline & $\begin{array}{c}\text { University } \\
\text { degree }\end{array}$ & $0(0)$ & $2(0.3)$ & $2(0.3)$ & \\
\hline & Total & $80(100)$ & $677(100)$ & $757(100)$ & \\
\hline \multirow{4}{*}{ Income (Tomans) } & $\begin{array}{c}\text { Less than } 4 \\
\text { million }\end{array}$ & $38(47.5)$ & $392(57.9)$ & $430(56.8)$ & \multirow{4}{*}{0.001} \\
\hline & 1-3 million & $34(42.5)$ & $278(41.1)$ & $312(41.2)$ & \\
\hline & $\begin{array}{l}\text { More than } 3 \\
\text { million }\end{array}$ & $8(10)$ & $7(1)$ & $15(2)$ & \\
\hline & Total & $80(100)$ & $677(100)$ & $757(100)$ & \\
\hline \multirow{4}{*}{$\begin{array}{l}\text { Treatment } \\
\text { method }\end{array}$} & Medication & $65(81.3)$ & $576(85.1)$ & $641(84.7)$ & \multirow{4}{*}{0.001} \\
\hline & Insulin & $6(7.5)$ & $46(6.8)$ & $52(6.9)$ & \\
\hline & $\begin{array}{l}\text { Medication and } \\
\text { insulin } \\
\end{array}$ & $9(11.3)$ & $55(8.1)$ & $64(8.5)$ & \\
\hline & Total & $80(100)$ & $677(100)$ & 757(100) & \\
\hline \multirow{7}{*}{$\begin{array}{l}\text { Age at time of } \\
\text { onset (years) }\end{array}$} & $12-19$ & $2(2.5)$ & $3(0.4)$ & $(0.6) 5(0.6)$ & \multirow{7}{*}{0.001} \\
\hline & $20-29$ & $0(0)$ & $10(1.5)$ & $10(1.3)$ & \\
\hline & $30-39$ & 9(11.3) & $71(10.5)$ & $80(10.6)$ & \\
\hline & $40-49$ & $36(45)$ & $217(32.1)$ & 253(33.4) & \\
\hline & $50-59$ & $22(27.5)$ & $228(33.7)$ & $250(33)$ & \\
\hline & $>60$ & $11(13.8)$ & $148(21.9)$ & 159(21) & \\
\hline & Total & $80(100)$ & $677(100)$ & $757(100)$ & \\
\hline \multirow{8}{*}{$\begin{array}{c}\text { History of } \\
\text { diabetes (years) }\end{array}$} & Less than 2 & $0(0)$ & $127(18.8)$ & $127(16.8)$ & \multirow{8}{*}{0.063} \\
\hline & $2-5$ & $28(35)$ & $139(20.5)$ & $167(22.1)$ & \\
\hline & $6-9$ & $15(18.8)$ & $152(22.5)$ & $167(22.1)$ & \\
\hline & $10-14$ & $23(28.8)$ & $118(17.4)$ & 141(18.6) & \\
\hline & $15-19$ & $7(8.8)$ & $76(11.2)$ & $83(11)$ & \\
\hline & $20-24$ & $3(3.8)$ & $39(5.8)$ & $42(5.5)$ & \\
\hline & $>25$ & $4(5)$ & $26(3.8)$ & $30(4)$ & \\
\hline & Total & $80(100)$ & $677(100)$ & $757(100)$ & \\
\hline \multirow{4}{*}{$\begin{array}{c}\text { History of } \\
\text { diabetes } \\
\text { complications }\end{array}$} & Yes & $25(31.3)$ & $152(22.5)$ & $177(23.4)$ & \multirow{4}{*}{0.001} \\
\hline & No & $55(68.7)$ & $525(77.5)$ & $580(76.6)$ & \\
\hline & Total & $80(100)$ & $677(100)$ & 757(100) & \\
\hline & كل & $80(100)$ & $677(100)$ & 757(100) & \\
\hline \multirow{3}{*}{$\begin{array}{l}\text { History of } \\
\text { Smoking }\end{array}$} & Yes & $39(48.8)$ & $20(3)$ & $59(7.8)$ & \multirow{3}{*}{0.83} \\
\hline & No & $41(51.2)$ & $57(97)$ & $698(92.2)$ & \\
\hline & Total & $80(100)$ & $677(100)$ & $757(100)$ & \\
\hline \multirow{3}{*}{$\begin{array}{l}\text { Smoking in the } \\
\text { past } 30 \text { days }\end{array}$} & Yes & $32(40)$ & $14(2.1)$ & $46(6.1)$ & \multirow{3}{*}{0.04} \\
\hline & No & $48(60)$ & 663(97.9) & 711(93.9) & \\
\hline & Total & $80(100)$ & $677(100)$ & $757(100)$ & \\
\hline \multirow{3}{*}{$\begin{array}{c}\text { History of } \\
\text { substance abuse } \\
\text { in first-degree } \\
\text { family members }\end{array}$} & Yes & $39(48.8)$ & $46(6.8)$ & $85(11.2)$ & \multirow{3}{*}{0.83} \\
\hline & No & $41(51.2)$ & 631(93.2) & $672(88.8)$ & \\
\hline & Total & $80(100)$ & $677(100)$ & $757(100)$ & \\
\hline \multirow{3}{*}{$\begin{array}{c}\text { Having diabetes } \\
\text { before substance } \\
\text { abuse }\end{array}$} & Yes & $45(56.3)$ & $(0)$ & $45(5.9)$ & \multirow{3}{*}{0.55} \\
\hline & No & $35(43.7)$ & $677(0)$ & $712(94.1)$ & \\
\hline & Total & $80(100)$ & $677(0)$ & $757(100)$ & \\
\hline
\end{tabular}




\section{DISCUSSION}

In the present study, we found that $9.3 \%$ of all diabetic patients were suffering from substance abuse. This rate in similar studies conducted in Iran varied between $10.4 \%$ and $11.2 \%(9,11,15)$.

In a study in Pakistan (16) and Malaysia (17), $27 \%$ and $8 \%$ of diabetics were smokers, respectively. In this regard, factors such as age, sex, social status, underlying diseases, place of residence, etc., can affect this rate (9). Given that the majority of participants in the present study were women $(70.9 \%)$ and the fact that the rate of substance abuse is lower in women (18), it seems that the frequency of substance abuse among diabetic patients may be higher than the estimated rate in our study.

In our study, $76.3 \%$ of all individuals with a history of substance abuse were men. In line with this finding, a similar study in Tehran found that diabetic men were more likely to abuse illicit drugs compared to diabetic women (11). A study in Pakistan also found that smoking was more frequent among diabetic men (16).

More than $80 \%$ of diabetic substance abusers were 50 years of age and older. We also found that substance abuse was more common among married individuals, farmers, people with primary education and those who had diabetes for 2-5 years.

The most commonly abused substances were opium and its derivatives. It is known that older people in Iran generally have a higher tendency toward consumption of traditional drugs such as opium. In addition, the high frequency of substance abuse among this age group could be related to the high frequency of diseases such as cardiovascular disease, hypertension and diabetes in this age group. In a study in Bojnord, one out of every four elderly people consumed opium, which is more than 8 -fold higher than the national average rate of opium consumption among the elderly population (19). In a study in an African country, the most commonly abused substances among diabetics were khat and alcohol (5). The frequent opium abuse among diabetic patients could be related to cultural and social factors as well as easy access to opium, belief in its beneficial effects and its arbitrary use (7).

Nearly three-quarters of diabetic patients who currently suffered from substance abuse used it solely to control diabetes and its side effects. Substance abuse, particularly opium abuse, with the aim to control or alleviate pain has been frequently observed in patients with chronic diseases. In a study in Mashhad, $9.3 \%$ of patients used opioids to relieve pain (20). Considering the adverse effects of drug abuse on the treatment outcome in diabetic patients, it is essential to pay extra attention to this group of patients and raise awareness about the health consequences of drug abuse (13-15).

The basis for diagnosing substance abuse in diabetic patients was self-reporting, and conventional laboratory tests were not used for this purpose, which could be a limitation of the present study.

\section{CONCLUSION}

The prevalence of substance abuse is $9.3 \%$ among diabetic patients living in rural areas of Bandar-e-Gaz. Based on the results, substance abuse is more common among middle-aged men, farmers, married individuals as well as people with primary education and those with diabetes for 2-5 years. Furthermore, opium is the most commonly abused drug in the study area.

\section{ACKNOWLEDGEMENTS}

The results of the study have been derived from results of a research project approved and supported by the Golestan University of Medical Sciences (project code: 97060699).

The authors would like to thank the Health Management and Social Development Research Center and the staff of health centers in Bandar-e-Gaz. 


\section{DECLARATIONS}

\section{Funding}

This study received financial support from the Golestan University of Medical Sciences, Iran.

\section{Ethics approvals and consent to participate}

Written informed consent was obtained from all patients prior to participation in the study. The subjects were assured that their personal information remain confidential. The study received approval from the ethics committee of the Golestan University of Medical Sciences, Iran (ethics code: IR.GOUMS.REC. 1397.113).

\section{Conflict of interest}

The author declares that there is no conflict of interest regarding publication of this article.

\section{REFERENCES}

1. Kohian H, Sohrabi MB, Zolfaghari P, et al. The prevalence and related factors of diabetic retinopathy in Shahroud. J Knowledge Health. .2012;7(4):179-84.

2. Harrison's Endocrinology, 4E / Edition 4. McGraw-Hill Professional Publishing; 2016.

3. Olfatifar M, Karami M, Hosseini S M, et al. Prevalence of Chronic Complications and Related Risk Factors of Diabetes in Patients Referred to the Diabetes Center of Hamedan Province. Sci J Hamadan Nurs Midwifery Fac. 2017; 25 (2) :69-74.

https://doi.org/10.21859/nmj-25029

4. Guariguata L. By the numbers: new estimates from the IDF Diabetes Atlas Update for 2012. Diabetes Res Clin Pract. 2012;98(3):524-5. https://doi.org/10.1016/j.diabres.2012.11.006

5. Kohian H, Sohrabi MB, Zolfaghari P, et al. The prevalence and related factors of diabetic retinopathy in Shahroud]. J Knowledge Health. 2012;7(4):179-84.

6. Amare Tizazu, Yimam Hussien, Salim Mebratu, et al. Substance ues among diabeticpatients in dessie referral hospital, northeast. Ethiopia. Research Desk, 2012; 1(1).40-46.

https://doi.org/10.1186/2049-9957-2-6

7. Mohammadinia A, Jalilian J, Shayeste Y.Characteristics of Patients Hospitalized with drug and substance abuse in Gorgan, Iran, 20082015 . IJEC. 2017; 1 (1) :69-76.

8. Razzaghi E, Rahimi A, Hosseini M, Chatterjee A. Rapid Situation Assessment (RSA) of drug abuse in Iran. Prevention Department, State Welfare Organization, Ministry of Health, IR of Iran and United Nations International Drug Control Program. 1999.

9. Fatehi R, Hashemnejad M, Mirdamadi M, et al. he Frequency of Opium Addiction and Cofactors in Diabetic Patients Referred to Karaj Shariati Hospital in 1389-90. International Journal of Medical Toxicology and Forensic Medicine. 2013;3(3): 75-79.

10. Dehghani K, Zare A, Dehghani H. Drug abuse prevalence and risk factors in students of shaheed Sadougi university of medical sciences, Yazd. J Shaeed Sadoughi university of Medical Sciences Yazd. 2010;73:164.

11. Sadr S, Mahmoudinia S, Bakhtiari M. Frequency of Opium Use among Diabetic Patients and Their Attitude. IJPBS.2009;3(2): 33-38.11

12. .Longo DL, Fauci AS, Kasper DL. Harrison's principles of internal medicine. 18th ed. U.S.A. Mc Graw Hill. 2012;2980- 2988 .

13. Ramsey SE., Anglers PA. Review: At-Risk Drinking Among Diabetic Patients. Substance. Abuse: Research and treatment. 2009;3:15-23 . https://doi.org/10.4137/SART.S2243

14. .Kebede Y, Abula T, Ayele B, et al. Module on substance abuse: For the Ethiopian Health Center Team. University of Gondar In collaboration with the Ethiopia Public Health Training Initiative, The Carter Center, the

Ethiopia Ministry of Health, and the Ethiopia Ministry of Education; April 2005.

15. .Shiri R, Hassani KF, Ansari M. Association between opium abuse and 
comorbidity in diabetic men. Am J Addict. 2006;15(6):468-72 .

https://doi.org/10.1080/10550490601000421

16. Naila K, Ejaz A, Shifa S, et al. Prevalence and Associated Factors of Cigarette Smoking among Type 2 Diabetes Patients in Pakistan. International Journal of Collaborative Research on Internal Medicine \& Public Health. 2014;6(4).

17. Ali Q Blebil1, Syed A, Mohamed A. et al. Evaluation of Smoking Status among Diabetes Patients in the State of Penang, Malaysia. .Tropical Journal of Pharmaceutical Research. 2013; 12 (3): 445-448

https://doi.org/10.4314/tjpr.v12i3.26

18. Khademi H, Malekzadeh R, Pourshams A. Opium use and mortality in Golestan cohort study: prospective cohort study of 50,000 adults in Iran. BMJ. 2012;344:2502.

https://doi.org/10.1136/bmj.e2502

19. Ghavam P, Sharifi F, Fakhrzadeh H, Motlagh M, Nazari N. Health status of elderly people in north khorasan: a cross-sectional study. Iranian Journal of Diabetes and Metabolism. 2017;16(4):219-30.

20. Saeidian SR, Ashrafizadeh S, Pakseresht S. Opium Abuse among Patients with Chronic Physical Pain as a Misleading Cause in Addiction Treatment Center. medical journal of mashhad university of medical sciences. 2011;54(2):83-93..

How to Cite: Shokrzadeh M, Savarolia A, Jafari D, Hoseinpoor R, Serayeloo H, Masodi E, et al .

Prevalence of Substance Abuse and Related Factors in Type 2 Diabetic Patients Living in a Rural Area in Northern Iran. jcbr. 2020; 4 (4) :41-49 